\title{
ALLELOPATHIC EFFECTS OF AQUEOUS AND ORGANIC FRACTIONS OF Euphorbia dracunculoides LAM. ON GERMINATION AND SEEDLING GROWTH OF CHICKPEA AND WHEAT
}

\author{
Asif Tanveer ${ }^{1}$, Muhammad Kamran Jabbar ${ }^{1}$, Abdul Kahliq ${ }^{1}$, Amar Matloob ${ }^{\mathbf{1}}$, Rana Nadeem Abbas ${ }^{1}$, \\ and Muhammad Mansoor Javaid ${ }^{2}$
}

\begin{abstract}
Identification of weed species with allelopathic potential and characterization of their adverse effects against associated crops is required for better understanding of weed-crop interactions. Phytotoxic activity of Euphorbia dracunculoides Lam. on germination and seedling growth of chickpea (Cicer arietinum L.) and wheat (Triticum aestivum L.) was investigated under controlled conditions. Two separate studies were done with each of four organic solvent fractions (n-hexane, chloroform, ethylacetate, 1-butanol) and crude aqueous (1:10 and 1:20) whole plant fractions of $E$. dracunculoides using distilled water and $0.05 \%(\mathrm{v} / \mathrm{v})$ dimethyl sulfoxide (DMSO) as control. Different aqueous and organic fractions of $E$. dracunculoides had a significant bearing on germination attributes and seedling growth that varied among tested species. The final germination percentage of wheat remained unaffected; nevertheless, root and shoot elongation and biomass accumulation in these parts were significantly retarded. Aqueous fractions appeared more phytotoxic than organic fractions and suppressed chickpea germination by $35-53 \%$. These aqueous fractions also reduced root (64-75\% and 33-34\%) and shoot (18-62\% and $21 \%$ ) length and root (32-33\% and $42-46 \%)$ and shoot (7-32\% and 80-84\%) dry weight of wheat and chickpea, respectively. Among organic fractions, $\mathrm{n}$-hexane was more suppressive to test species. Chromatographic analysis revealed the presence of four phytotoxins, furoic, $p$-coumaric, syringic, and caffeic acids, in aqueous whole plant (1:10) fractions. This study determined the phytotoxic allelopathic activity of $E$. dracunculoides against wheat and chickpea.
\end{abstract}

Key words: Allelopathy, weeds, germination attributes, suppression, phenolics.

$\mathrm{W}$ eeds are the most prevalent or dominant class of pests and interfere with crop plants through competition and allelopathy, resulting in direct quantity and quality loss of produce. Allelopathy is a mechanism that weeds often utilize to affect germination dynamics and growth of field crops (Qasem and Foy, 2001; Kadioglu et al., 2005; Benyas et al., 2010) in order to establish weedy monoculture by influencing species patterning in agro-ecosystems (Weston and Duke, 2003). Living as well as dead weed tissues that are left in the soil after completing the life cycle can have deleterious effects on the same or subsequent crops by releasing allelochemicals (Batish et al., 2007). These allelochemicals are reported to be present in almost all plant parts, including stems, leaves, flowers, buds, pollen grains, seeds, fruits, roots, and rhizomes (Rice, 1984; Singh et al., 2003). However, differences are observed among species regarding their

\footnotetext{
${ }^{1}$ University of Agriculture, Department of Agronomy, Faisalabad, Pakistan. .Corresponding author (agronomistryk@gmail.com).

${ }^{2}$ University of Sargodha, University College of Agriculture, University Road, Sargodha, Pakistan.

Received: 15 April 2012.

Accepted: 23 July 2012.
}

allelopathic potential and their ability to produce toxins in various parts (Qasem and Foy, 2001; Veenapani, 2004).

Among 7500 species of Euphorbiaceae, many are known as weeds that exert allelopathic activity on crops. The allelopathic potential of extracts, residues and root secretions of Euphorbia corollata L. (Rice, 1964), E. esula L. (Manners, 1987), E. geniculata Ortega (Sugha, 1979), E. granulata Forssk (Hussain, 1980), E. hirta L. (Tiwari et al., 1985), E. prostrata Aiton (Alsaadawi et al., 1990), E. hierosolymitana Boiss. (Abu-Romman et al., 2010) and E. helioscopia L. (Qasem, 1995; Tanveer et al., 2010) have been reported against crops like pea, tomato, wheat, chickpea, cotton, alfalfa, lettuce, groundnut, and soybean. Allelopathic activity has been attributed to several phytotoxins like phenolic acids (gallic, tannic), kaemferol 3-glucuronide and 1-hexacosanol (Rice, 1969; Manners, 1987) present in these species.

Beside these species, dragon spurge (E.dracunculoides Lam.) is also an important component of weed flora in winter crops like wheat and chickpea (Marwat et al., 2004; Tanveer, 2008), especially in rainfed areas. Identification of weed species with allelopathic potential and characterization of their adverse effects against associated crops is required for a better understanding 
of weed-crop interactions. Moreover, magnitude of allelopathic suppression is believed to vary with sample preparation and extraction techniques (Zieliński and Kozłowska, 2000; Javaid et al., 2011). Little is known about the allelopathic influence of E. dracunculoides against associated crops. The following studies therefore were conducted to evaluate the allelopathic potential of $E$. dracunculoides on germination and early seedling growth of wheat (Triticum aestivum L.) and chickpea (Cicer arientinum L.), main cereal and pulse crops in Pakistan.

\section{MATERIALS AND METHODS}

\section{Seed source}

Seeds of wheat ('Sehar-2006') and chickpea ('CM-2000') were obtained from Ayub Agriculture Research Institute, Faisalabad, Pakistan. The seeds were manually cleaned to ensure physical purity and the surfaces were sterilized with fungicide.

\section{Extraction and portioning of E. dracunculoides plant material}

Field grown plants of $E$. dracunculoides were uprooted at maturity (with seeds enclosed in fruit) and dried at room temperature. The well-dried plant material was chopped into 2-3 cm pieces and dried in an oven at $70{ }^{\circ} \mathrm{C}$ for 48 h. The oven-dried material was ground (Cyclotec 1093 Sample Mill, Sweden) and passed through a 40-mesh screen. The ground material (1 kg) was extracted in $3 \mathrm{~L}$ of $80 \%$ ethanol-water solution at room temperature for $24 \mathrm{~h}$. The aqueous ethanolic extract of whole plant was obtained by filtering extracts through a filter paper using a vacuum pump (type N820.3FT18, KNF Neuberger $\mathrm{GmbH}$, Freiburg-Munzingen, Germany). This filtrate was concentrated to crude brown gum, which was then dissolved in $1 \mathrm{~L}$ distilled water, acidified with $10 \%$ acetic acid ( $\mathrm{pH} 4)$, washed with hexane to remove fats and neutral material. It was sequentially portioned against $n$-hexane, chloroform, ethyl acetate, 1-butanol, and water (Figure 1). Each of the four organic solvent fractions were dried over anhydrous $\mathrm{Na}_{2} \mathrm{SO}_{4}$ and evaporated to dryness below $40{ }^{\circ} \mathrm{C}$. Different fractions were weighed and dissolved in $0.05 \%(\mathrm{v} / \mathrm{v})$ dimethyl sulfoxide (DMSO). The extracts were collected in separate bottles (stock) and tagged.

\section{Bioassay}

Ten seeds each of wheat and chickpea were placed evenly on Whatman \# 42 filter paper in sterilized Petri dishes of $9 \mathrm{~cm}$ diameter. Five $\mathrm{mL}$ of respective organic solvent fraction or crude extract was added to Petri dishes as treatment. The same volume of distilled water and $0.05 \%$ DMSO was applied to two separate control treatments. Half of the solution was used to moisten the filter paper receiving seeds while the remaining half was applied to the covering filter paper. The Petri dishes were maintained under laboratory conditions (room temperature $25^{\circ} \mathrm{C} \pm 2$

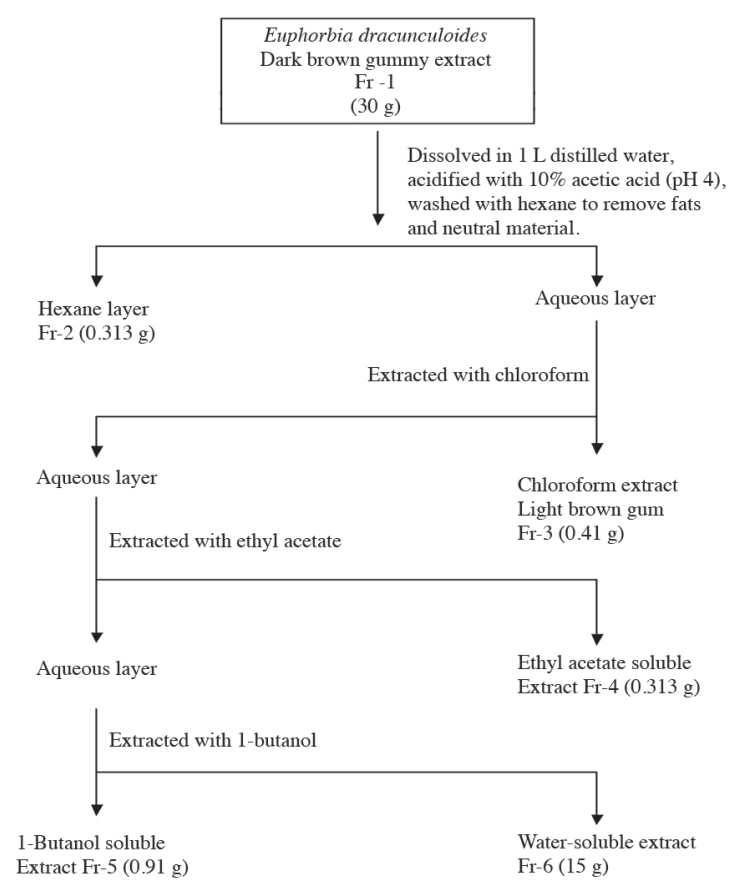

Figure 1. Scheme showing the procedure for extraction and portioning of dried ethanol extract of Euphorbia dracunculoides (adapted from Iqbal et al., 2002).

at midday with diffused light during day) for $2 \mathrm{wk}$. The same volume of distilled water was added to the dishes when the moisture content of the filter paper decreased. The outer filter paper was removed just before the initiation of germination.

Germination counts were recorded on a daily basis according to AOSA (1990) until a constant count was achieved. Seeds were considered to have germinated when the radicle and hypocotyl lengths were over $2 \mathrm{~mm}$.

The time elapsed before $50 \%$ emergence $\left(\mathrm{E}_{50}\right)$ was calculated according to the modified formulae of Farooq et al. (2005):

$$
E_{50}=t_{i}+\frac{\left(\frac{N}{2}-n_{i}\right)\left(t_{j}-t_{i}\right)}{n_{j}-n_{i}}
$$

where $\mathrm{N}$ is the final number of emerged seeds, and $n_{i}$ and $n_{j}$ are the cumulative number of seeds emerged by adjacent counts at times $t_{i}$ and $t_{j}$ where $n_{i}<N / 2<n_{j}$.

Mean emergence time (MET) was calculated according to Ellis and Roberts (1981) as:

$$
\mathrm{MET}=\Sigma \mathrm{Dn} / \Sigma \mathrm{n}
$$

where $n$ is the number of seeds, which were emerged on day $D$, and $D$ is the number of days counted from the beginning of emergence.

Emergence Index was computed as described by AOSA (1983):

$E I=\frac{N^{o} \text { of emerged seeds }}{\text { Days of first count }}+------+\frac{N^{o} \text { of emerged seeds }}{\text { Days of final count }}$ 
Root and shoot lengths were measured after $14 \mathrm{~d}$ with a measuring tape. All roots and shoots from each Petri dish were cut separately and oven dried at $70{ }^{\circ} \mathrm{C}$ for $48 \mathrm{~h}$ to get dry biomass of root and shoot. The seedling vigor index was calculated according to the following formula of Abdul-Baki and Anderson (1973) as:

$$
\text { SVI }=\text { Germination }(\%) \times \text { Radicle length }(\mathrm{cm})
$$

\section{Detection of phytotoxins and bioassays with detected compounds}

Due to their greater suppression potential, aqueous $E$. dracunculoides extracts were chemically analyzed with the High Performance Liquid Chromatography system (Model SCL-10A, Shimadzu HPLC, Tokyo, Japan) for identification and quantification of suspected phytotoxins. The separation conditions are listed in Table 1.

The peaks were detected by a UV detector. Standards of suspected phytotoxins (Aldrich, St. Louis, Missouri, USA) were run for identification and quantification. Standards of phenolics were prepared in different concentrations. Furoic, coumaric, syringic, and caffeic acids were identified by their retention time with authentic standards. The concentration of each isolated compound was determined by the following equation:

Table 1. HPLC conditions to determine phytotoxins in aqueous Euphorbia dracunculoides extracts (whole plant 1:10).

\begin{tabular}{ll}
\hline Parameter & \multicolumn{1}{c}{ Characteristic } \\
\hline Column dimensions & $25 \mathrm{~cm}$ length $\times 4.6 \mathrm{~mm}$ diameter, particle size $5 \mu \mathrm{m}$ \\
Diatomite & Supleco wax 10 \\
Attenuation & $0.01 \mathrm{mg} \mathrm{L}^{-1}$ \\
Rate of recorder & $10 \mathrm{~mm} \mathrm{~min}^{-1}$ \\
Detector & $\mathrm{SPD}-10 \mathrm{~A} \mathrm{vp}$-detector \\
Detection & $\mathrm{UV}, 280 \mathrm{~nm}$ \\
Flow rate & $0.25 \mathrm{~mL} \mathrm{~min}^{-1}$ \\
Volume injection sample & $50 \mu \mathrm{L}$ \\
Type of column & Shim-pack CLC-octadecyl silicate (ODS) (C-18) \\
Mobile phase & Isocratic; $100 \%$ methanol \\
Temperature & $25^{\circ} \mathrm{C}$ \\
\hline
\end{tabular}

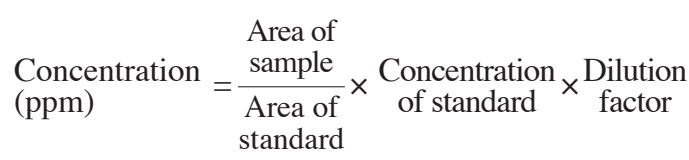

The activities of the identified compounds were evaluated with the seed of both tested species. An equimolar solution of analytical grade furoic, $p$-coumaric, syringic, and caffeic acids $\left(10^{-3} \mathrm{M}\right)$ was prepared in distilled water. The solution was stored at $5{ }^{\circ} \mathrm{C}$ until subsequent use.

Twenty seeds each of chickpea and wheat were placed separately and uniformly on a Whatman \# 42 filter papers in a $9-\mathrm{cm}$ diameter Petri dishes. Some $5 \mathrm{~mL}$ of tested solution of each phytotoxin was applied in respective Petri dishes. A distilled water control was maintained for each tested species. Germination percentages of test species were recorded using standard procedures (AOSA, 1990). The percentage of germination was determined after a constant count was achieved.

\section{Experimental design and statistical analysis}

All the experiments were quadruplicated in a completely randomized design and repeated twice. A separate experiment was conducted for each tested species. Treatment means were separated by the Least Significant Differences test (LSD) at $\mathrm{P} \leq 0.05$. Data were analyzed following an ANOVA with MSTAT-C software.

\section{RESULTS AND DISCUSSION}

Germination traits of wheat and chickpea were negatively influenced by aqueous and organic fractions of $E$. dracunculoides (Table 2). There were significant ( $\mathrm{P} \leq$ $0.05)$ delays in $\mathrm{E}_{50}$ over control in all the treatments of both wheat and chickpea. However, these delays were more pronounced for chickpea, in which the n-hexane fraction accounted for the maximum delay and was at $\operatorname{par}(\mathrm{P} \leq 0.05)$ with the chloroform fraction. On the other

Table 2. Influence of aqueous and organic fractions of Euphorbia dracunculoides extracts on germination attributes of wheat and chickpea.

\begin{tabular}{|c|c|c|c|c|c|c|c|c|}
\hline \multirow[b]{2}{*}{ Treatment } & \multicolumn{2}{|c|}{$\mathrm{E}_{50}$} & \multicolumn{2}{|c|}{ Final germination } & \multicolumn{2}{|c|}{ Mean germination time } & \multicolumn{2}{|c|}{ Emergence index } \\
\hline & Wheat & Chickpea & Wheat & Chickpea & Wheat & Chickpea & Wheat & Chickpea \\
\hline & $\longrightarrow$ & $\longrightarrow$ & $\longrightarrow$ & $\overline{-}$ & $\longrightarrow$ & $\overline{-}$ & & \\
\hline Water (control) & $2.34 \mathrm{ab}$ & $2.20 \mathrm{~d}$ & $100.00^{\text {ns }}$ & $85.00 \mathrm{a}$ & $2.35 \mathrm{~d}$ & $2.47 \mathrm{e}$ & $4.62 b$ & $6.56 \mathrm{a}$ \\
\hline Aqueous extract ( $1: 10)$ & $\begin{array}{r}2.51 \mathrm{a} \\
(7)^{1}\end{array}$ & $\begin{array}{r}4.16 \mathrm{~b} \\
(89)\end{array}$ & $\begin{array}{c}100.00 \\
(0)\end{array}$ & $\begin{array}{c}35.00 \mathrm{f} \\
(-53)\end{array}$ & $\begin{array}{c}4.13 \mathrm{ab} \\
(76)\end{array}$ & $\begin{array}{c}3.59 \mathrm{~cd} \\
(53)\end{array}$ & $\begin{array}{l}1.42 d \\
(-69)\end{array}$ & $\begin{array}{l}1.23 \mathrm{e} \\
(-81)\end{array}$ \\
\hline Aqueous extract (1:20) & $\begin{array}{c}2.41 \mathrm{ab} \\
\text { (3) }\end{array}$ & $\begin{array}{c}2.60 \mathrm{~cd} \\
(18)\end{array}$ & $\begin{array}{c}100.00 \\
(0)\end{array}$ & $\begin{array}{c}55.00 \mathrm{~d} \\
(-35)\end{array}$ & $\begin{array}{r}3.46 \mathrm{c} \\
(47)\end{array}$ & $\begin{array}{c}3.60 \mathrm{~cd} \\
(53)\end{array}$ & $\begin{array}{l}1.58 \mathrm{~d} \\
(-66)\end{array}$ & $\begin{array}{l}1.47 \mathrm{e} \\
(-78)\end{array}$ \\
\hline $0.5 \%$ DMSO & $\begin{array}{r}1.82 \mathrm{c} \\
(-22)\end{array}$ & $\begin{array}{r}2.67 \mathrm{c} \\
(21)\end{array}$ & $\begin{array}{c}100.00 \\
(0)\end{array}$ & $\begin{array}{c}75.00 \mathrm{~b} \\
(-12)\end{array}$ & $\begin{array}{r}4.35 \mathrm{a} \\
(85)\end{array}$ & $\begin{array}{c}4.56 \mathrm{a} \\
(94)\end{array}$ & $\begin{array}{l}3.65 c \\
(-21)\end{array}$ & $\begin{array}{l}4.29 c \\
(-35)\end{array}$ \\
\hline n-Hexane & $\begin{array}{c}2.56 \mathrm{a} \\
(9)\end{array}$ & $\begin{array}{r}4.61 \mathrm{a} \\
(109)\end{array}$ & $\begin{array}{c}100.00 \\
(0)\end{array}$ & $\begin{array}{c}45.00 \mathrm{e} \\
(-47)\end{array}$ & $\begin{array}{r}4.60 \mathrm{a} \\
(96)\end{array}$ & $\begin{array}{c}4.11 b c \\
(75)\end{array}$ & $\begin{array}{l}3.34 c \\
(-28)\end{array}$ & $\begin{array}{c}3.99 \mathrm{c} \\
(39)\end{array}$ \\
\hline Chloroform & $\begin{array}{c}2.16 b \\
(-7)\end{array}$ & $\begin{array}{c}4.38 \mathrm{ab} \\
(99)\end{array}$ & $\begin{array}{c}100.00 \\
(0)\end{array}$ & $\begin{array}{c}55.00 \mathrm{~d} \\
(-35)\end{array}$ & $\begin{array}{r}4.62 \mathrm{a} \\
(97)\end{array}$ & $\begin{array}{l}4.95 \mathrm{a} \\
(111)\end{array}$ & $\begin{array}{l}3.46 \mathrm{c} \\
(-25)\end{array}$ & $\begin{array}{l}3.37 d \\
(-49)\end{array}$ \\
\hline Ethylacetate & $\begin{array}{c}1.68 \mathrm{c} \\
(-28)\end{array}$ & $\begin{array}{c}2.51 \mathrm{~cd} \\
(14)\end{array}$ & $\begin{array}{c}100.00 \\
(0)\end{array}$ & $\begin{array}{c}65.00 \mathrm{c} \\
(-23)\end{array}$ & $\begin{array}{r}4.38 \mathrm{a} \\
(86)\end{array}$ & $\begin{array}{c}4.52 \mathrm{ab} \\
(92)\end{array}$ & $\begin{array}{l}3.55 \mathrm{a} \\
(-23)\end{array}$ & $\begin{array}{l}5.50 b \\
(-16)\end{array}$ \\
\hline 1-Butanol & $\begin{array}{c}2.39 \mathrm{ab} \\
(2)\end{array}$ & $\begin{array}{l}2.27 \mathrm{~cd} \\
\text { (3) }\end{array}$ & $\begin{array}{c}100.00 \\
(0)\end{array}$ & $\begin{array}{c}55.00 \mathrm{~d} \\
(-35)\end{array}$ & $\begin{array}{c}3.63 \mathrm{bc} \\
(54)\end{array}$ & $\begin{array}{r}3.44 d \\
(46)\end{array}$ & $\begin{array}{l}3.47 \mathrm{c} \\
(-25)\end{array}$ & $\begin{array}{l}3.45 d \\
(-47)\end{array}$ \\
\hline $\mathrm{LSD} \leq 0.05$ & 0.292 & 0.423 & - & 8.426 & 0.603 & 0.524 & 0.336 & 0.484 \\
\hline
\end{tabular}

Means with different letters differ at $5 \%$ level of probability by LSD test.

${ }^{1}$ Numbers given in parenthesis show percent change over control. ns: non significant. 
hand, final germination of wheat remained unaffected by the extract application. Final germination of chickpea was inhibited principally $(53 \%)$ by the aqueous $(1: 10)$ fraction, followed by the n-hexane fraction at $47 \%$. The aqueous (1:20) and chloroform fractions were responsible for statistically similar suppression of final chickpea germination. Mean emergence time of wheat and chickpea was also increased by all the aqueous and organic fractions over control. The chloroform fraction scored maximum (97 and $111 \%$ ) delays in MGT for wheat and chickpea, respectively, and it was statistically similar $(\mathrm{P} \leq$ $0.05)$ with the n-hexane and aqueous fractions for wheat, and the ethyl acetate fraction for chickpea. Significantly $(\mathrm{P} \leq 0.05)$ lower EI values than those for control were also recorded. Drastic reductions in EI compared to those of the control were obtained by aqueous fractions (1:10 and 1:20) for both wheat and chickpea and were statistically similar $(\mathrm{P} \leq 0.05)$.

Root and shoot length of wheat and chickpea were also significantly $(\mathrm{P} \leq 0.05)$ suppressed by the aqueous and organic fractions of $E$. dracunculoides (Table 3). Aqueous fractions caused significant reduction in root $(64-75 \%$ and $33-34 \%$ ) and shoot (18-62\% and $21 \%$ ) length over control in wheat and chickpea, respectively. Among the organic fractions, n-hexane and chloroform were most significant in retarding root and shoot elongation of the tested species. Shoot and root dry weight was also reduced under all treatments over control. Aqueous fractions scored maximum reduction in root (32-33\% and $42-46 \%)$ and shoot (7-32\% and $80-84 \%)$ dry weight of wheat and chickpea, respectively. Among the organic fractions, n-hexane accounted for greater suppression in root (19 and 35\%) and shoot (5 and 75\%) dry weight of wheat and chickpea, respectively. Significantly $(\mathrm{P} \leq 0.05)$ lower SVI values than those of the control were obtained by the aqueous $E$. dracunculoides fractions, which were statistically similar $(\mathrm{P} \leq 0.05)$ to those obtained with organic fractions of $\mathrm{n}$-hexane and chloroform. Wheat seedling growth was improved by $0.5 \%$ DMSO compared to the distilled water control. Chromatographic analysis (Table 4) revealed the presence of four phytotoxins namely furoic, $p$-coumaric, syringic and caffeic acids in aqueous whole plant (1:10) fraction of E. dracunculoides. Furoic acid was the predominant $\left(904 \mathrm{mg} \mu \mathrm{L}^{-1}\right)$ compound detected in this fraction. A considerable amount of syringic acid was also found in aqueous whole plant fraction, while $p$-coumaric and caffeic acids were detected in lesser amounts. Bioassay with these detected compounds showed inhibition of chickpea and wheat germination over control. Maximum suppression of chickpea and wheat germination was obtained by syringic and caffeic acids, respectively, that was at par with syringic acid regarding wheat germination (Table 5).

Analysis and interpretation of the results reveal significant inhibition of germination dynamics (except wheat) and seedling growth of species tested under the influence of the different treatments. The suppression was allelopathic in nature, and detection of phytotoxic

Table 4. Chromatographic analysis of Euphorbia dracunculoides aqueous whole plant extracts (1:10).

\begin{tabular}{lcccccc}
\hline $\begin{array}{l}\text { Detected } \\
\text { compound }\end{array}$ & \multicolumn{2}{c}{$\begin{array}{c}\text { Retention } \\
\text { Concentration }\end{array}$} & $\begin{array}{r}\text { Peak } \\
\text { area }\end{array}$ & $\begin{array}{r}\text { Peak } \\
\text { area }\end{array}$ & $\begin{array}{c}\text { Peak } \\
\text { height }\end{array}$ & $\begin{array}{c}\text { Peak } \\
\text { height }\end{array}$ \\
\hline & $\mu \mathrm{g} \mathrm{mL}^{-1}$ & $\mathrm{~min}$ & $\mathrm{mV}$ & \multicolumn{1}{c}{$\%$} & $\mathrm{mV}$ & $\%$ \\
Furoic acid & 904 & 10.53 & 1440.7 & 18.4 & 17.77 & 9.3 \\
$p$-Coumaric acid & 1.21 & 12.99 & 184.24 & 2.3 & 5.98 & 3.1 \\
Syringic acid & 8.98 & 18.32 & 561.78 & 7.2 & 2.30 & 1.2 \\
Caffeic acid & 0.52 & 22.36 & 75.47 & 8.9 & 0.41 & 2.6
\end{tabular}

Table 5. Influence of detected phytotoxins on germination of wheat and chickpea.

\begin{tabular}{lcc}
\hline & \multicolumn{2}{c}{ Germination $(\%)$} \\
\cline { 2 - 3 } Tested phytotoxin & Wheat & Chickpea \\
\hline Control & $95.00 \pm 2.87 \mathrm{a}$ & $91.67 \pm 1.67 \mathrm{a}$ \\
Furoic acid & $83.33 \pm 1.67 \mathrm{~b}$ & $76.67 \pm 1.67 \mathrm{~b}$ \\
$p$-Coumaric acid & $83.33 \pm 1.67 \mathrm{~b}$ & $78.33 \pm 1.67 \mathrm{~b}$ \\
Syringic acid & $75.00 \pm 2.88 \mathrm{c}$ & $66.67 \pm 3.33 \mathrm{c}$ \\
Caffeic acid & $72.67 \pm 1.67 \mathrm{c}$ & $75.0 \pm 2.87 \mathrm{~b}$ \\
LSD $\leq 0.05$ & 7.046 & 7.427 \\
\hline
\end{tabular}

Means with different letters differ at $5 \%$ level of probability by LSD test.

Table 3. Influence of aqueous and organic fractions of Euphorbia dracunculoides extracts on seedling growth of wheat and chickpea.

\begin{tabular}{|c|c|c|c|c|c|c|c|c|c|c|}
\hline \multirow[b]{2}{*}{ Treatment } & \multicolumn{2}{|c|}{ Root length } & \multicolumn{2}{|c|}{ Shoot length } & \multicolumn{2}{|c|}{ Root dry weight } & \multicolumn{2}{|c|}{ Shoot dry weight } & \multicolumn{2}{|c|}{ Seedling vigor index } \\
\hline & Wheat & Chickpea & Wheat & Chickpea & Wheat & Chickpea & Wheat & Chickpea & Wheat & Chickpea \\
\hline & & 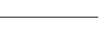 & & & 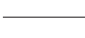 & $-\mathrm{mg} \mathrm{se}$ & ing $^{-1}$ & - & & \\
\hline Water (control) & $9.25 \mathrm{~b}$ & $3.40 \mathrm{a}$ & $9.28 \mathrm{a}$ & $3.35 \mathrm{a}$ & $67.75 b$ & $52.00 \mathrm{a}$ & $86.50 \mathrm{c}$ & $337.00 \mathrm{a}$ & $925.50 \mathrm{~b}$ & $257.78 \mathrm{a}$ \\
\hline $\begin{array}{l}\text { Aqueous extract } \\
(1: 10)\end{array}$ & $\begin{array}{r}2.34 f \\
(-75)\end{array}$ & $\begin{array}{r}2.29 \mathrm{~cd} \\
(-33)\end{array}$ & $\begin{array}{l}3.52 \mathrm{e} \\
(-62)\end{array}$ & $\begin{array}{l}2.41 b \\
(-21)\end{array}$ & $\begin{array}{c}46.25 d \\
(-32)\end{array}$ & $\begin{array}{c}30.00 \mathrm{de} \\
(-42)\end{array}$ & $\begin{array}{l}59.00 \mathrm{~d} \\
(-32)\end{array}$ & $\begin{array}{l}55.00 \mathrm{~g} \\
(-84)\end{array}$ & $\begin{array}{l}234.50 f \\
(-75)\end{array}$ & $\begin{array}{c}130.30 \mathrm{~cd} \\
(-49)\end{array}$ \\
\hline $\begin{array}{l}\text { Aqueous extract } \\
(1: 20)\end{array}$ & $\begin{array}{r}3.28 \mathrm{e} \\
(-64)\end{array}$ & $\begin{array}{r}2.25 \mathrm{~d} \\
(-34)\end{array}$ & $\begin{array}{r}7.61 \mathrm{c} \\
(-18)\end{array}$ & $\begin{array}{l}2.40 b \\
(-21)\end{array}$ & $\begin{array}{l}45.50 \mathrm{~d} \\
(-33)\end{array}$ & $\begin{array}{l}28.00 \mathrm{e} \\
(-46)\end{array}$ & $\begin{array}{c}80.75 c \\
(-7)\end{array}$ & $\begin{array}{l}66.00 \mathrm{fg} \\
(-80)\end{array}$ & $\begin{array}{l}328.50 \mathrm{e} \\
(-64)\end{array}$ & $\begin{array}{l}122.80 \mathrm{~d} \\
(-52)\end{array}$ \\
\hline $0.5 \%$ DMSO & $\begin{array}{c}13.01 \mathrm{a} \\
(40)\end{array}$ & $\begin{array}{r}3.45 \mathrm{a} \\
(2)\end{array}$ & $\begin{array}{c}9.13 \mathrm{ab} \\
(-2)\end{array}$ & $\begin{array}{c}3.53 \mathrm{a} \\
(16)\end{array}$ & $\begin{array}{c}90.75 \mathrm{a} \\
(34)\end{array}$ & $\begin{array}{l}44.75 b \\
(-14)\end{array}$ & $\begin{array}{l}91.25 \mathrm{ab} \\
(5)\end{array}$ & $\begin{array}{l}236.00 \mathrm{c} \\
(-30)\end{array}$ & $\begin{array}{c}1301.3 \mathrm{a} \\
(41)\end{array}$ & $\begin{array}{c}249.95 \mathrm{a} \\
(-3)\end{array}$ \\
\hline n-Hexane & $\begin{array}{l}2.57 \mathrm{ef} \\
(-72)\end{array}$ & $\begin{array}{r}2.65 b c \\
(-22)\end{array}$ & $\begin{array}{r}2.74 \mathrm{f} \\
(-70)\end{array}$ & $\begin{array}{l}2.31 b \\
(-24)\end{array}$ & $\begin{array}{l}54.75 c \\
(-19)\end{array}$ & $\begin{array}{c}34.00 \mathrm{~d} \\
(-35)\end{array}$ & $\begin{array}{l}82.00 \mathrm{c} \\
(-5)\end{array}$ & $\begin{array}{l}84.50 \mathrm{ef} \\
(-75)\end{array}$ & $\begin{array}{l}257.75 \mathrm{ef} \\
(-72)\end{array}$ & $\begin{array}{l}125.45 \mathrm{~d} \\
(-51)\end{array}$ \\
\hline Chloroform & $\begin{array}{l}2.89 \mathrm{ef} \\
(-69)\end{array}$ & $\begin{array}{r}2.72 b \\
(-20)\end{array}$ & $\begin{array}{r}6.01 d \\
(-35)\end{array}$ & $\begin{array}{l}2.41 b \\
(-21)\end{array}$ & $\begin{array}{l}58.50 \mathrm{c} \\
(-14)\end{array}$ & $\begin{array}{c}40.50 b c \\
(-22)\end{array}$ & $\begin{array}{l}88.00 \mathrm{abc} \\
(2)\end{array}$ & $\begin{array}{c}157.25 \mathrm{~d} \\
(-53)\end{array}$ & $\begin{array}{c}289.75 \mathrm{ef} \\
(-69)\end{array}$ & $\begin{array}{l}149.18 b c \\
(-42)\end{array}$ \\
\hline Ethyl acetate & $\begin{array}{r}4.17 d \\
(-55)\end{array}$ & $\begin{array}{r}2.76 b \\
(-19)\end{array}$ & $\begin{array}{c}8.67 b \\
(-6)\end{array}$ & $\begin{array}{l}2.46 b \\
(-19)\end{array}$ & $\begin{array}{l}70.25 b \\
(4)\end{array}$ & $\begin{array}{c}57.25 \mathrm{a} \\
(10)\end{array}$ & $\begin{array}{l}87.75 b c \\
\quad(1)\end{array}$ & $\begin{array}{c}269.25 b \\
(-20)\end{array}$ & $\begin{array}{l}417.75 d \\
(-55)\end{array}$ & $\begin{array}{c}168.65 b \\
(-35)\end{array}$ \\
\hline 1-Butanol & $\begin{array}{r}5.21 \mathrm{c} \\
(-44)\end{array}$ & $2.52 \mathrm{bcd}$ & $\begin{array}{r}7.08 \mathrm{c} \\
(-24)\end{array}$ & $\begin{array}{l}2.61 b \\
(-14)\end{array}$ & $\begin{array}{c}67.00 b \\
(-1)\end{array}$ & $\begin{array}{l}35.00 \mathrm{~cd} \\
(-33)\end{array}$ & $\begin{array}{c}95.25 \mathrm{a} \\
(10)\end{array}$ & $\begin{array}{l}95.50 \mathrm{e} \\
(-72)\end{array}$ & $\begin{array}{l}521.50 \mathrm{c} \\
(-44)\end{array}$ & $\begin{array}{l}145.98 \mathrm{bcd} \\
(-43)\end{array}$ \\
\hline $\mathrm{LSD} \leq 0.05$ & 0.732 & 0.397 & 0.597 & 0.382 & 8.392 & 5.810 & 7.417 & 20.634 & 73.252 & 23.544 \\
\hline
\end{tabular}

Means with different letters differ at $5 \%$ level of probability by LSD test.

${ }^{1}$ Numbers given in parenthesis show percent change over control. 
compounds (Table 4) and quantification of their adverse effects on germination of chickpea and wheat (Table 5) confirm this hypothesis. Chromatographic analysis provided additional insights into phytotoxin-mediated suppression of the tested species tested by determining the qualitative and quantitative presence of different compounds. A number of phenolic compounds responsible for inhibitory allelopathic activity of E. dracunculoides were identified in the present study; none of them previously reported in aqueous extracts of this weed. Chemical analyses revealed the presence of 2-furoic, caffeic, syringic, and $p$-coumaric acids in aqueous extracts of $E$. dracunculoides. Caffeic and $p$-coumaric acids are cinnamic acid derivatives while syringic acid is a benzoic acid derivative. Most of these compounds are watersoluble and when present in sufficient concentration can cause allelopathic activity in their immediate vicinity. These compounds are known to interfere with basic structures and functions in the tested species, causing various forms of stress resulting in impaired germination and diminished growth (Duke and Dayan, 2006). The suppression of chickpea germination in the aqueous whole plant fraction $(1: 10)$ was higher than that observed when the detected compounds were individually used in bioassays. Allelopathic activity is believed to arise from different chemicals acting additively or synergistically (Einhellig, 1996). Blum (1996) reported that mixtures of phenolic allelochemicals and other organic chemicals present in the substratum could cause inhibitory effects, although their individual concentrations are far below the threshold level to cause allelopathic activity.

Inhibition of plant growth by allelopathic compounds can be explained by induced changes in cell ultra structures, molecular biology, as well as biochemical and physiological attributes. Alteration in germination and seedling morphology under the influence of aqueous and organic fractions of E. dracunculoides can be a secondary expression of disturbances and alterations in these primary mechanisms (Weir et al., 2004; Gniazdowska and Bogatek, 2005). Aqueous extracts (1:10) exhibited more suppression of germination and seedling growth of species tested than aqueous extracts in 1:20. This could be attributed to increased concentration of individual phytotoxins or their compound effects in concentrated aqueous extract (1:10) of E. dracunculoides than the diluted one (1:20). Anjum and Bajwa (2010) reported pronounced increases in allelopathic inhibition due to the effect of doage. In addition to aqueous E. dracunculoides extracts, organic fractions also exhibited differential level of phytotoxicity against test species that might arise due to the variable chemical nature of the compounds used for extraction. Water is a polar compound while n-hexane is non-polar in nature. Variable phytotoxicity of different aqueous and organic fractions of E. dracunculoides might be due to different extraction efficiencies of the solvents used, accounting for qualitative and quantitative differences in extracted phytotoxins in different fractions. In our study, water appeared as the best solvent to be used for extraction of inhibitory compounds as shown by impaired germination and retarded seedling growth of aqueous extracts of $E$. dracunculoides, which was significantly higher than several other organic fractions. Whitehead et al. (1981) concluded that phenolics, a major category of compounds responsible for allopathic activity (Li et al., 2010), can best be extracted in water. Javaid et al. $(2010 ; 2011)$, while screening aqueous, methanol, and n-hexane extracts of Withania somnifera (L.) Dunal against Parthenium hysterophorus L. and Phalaris minor Retz., also concluded that highest allelopathic potential was in the water-soluble fraction. This allelopathic interference on behalf of water-soluble compounds is of great ecological significance particularly in cultivated fields that are infested with this weed and are frequently irrigated or receive rainwater.

In addition to the differential allelopathic potential exhibited by aqueous and organic fractions of $E$. dracunculoides, the tested species also varied in susceptibility and their response due to different attributes. The differential inhibition by allelopathic products is in agreement with findings of Khaliq et al. (2011). Wheat germination was not affected by any extract. The results of present study corroborate the findings of Tanveer et al. (2010), who reported that aqueous extracts of $E$. helioscopia suppressed germination and seedling growth of lentil and chickpea to a much greater extent than that of wheat, which was hardly affected or unaffected. Mishra et al. (2004) reported similar results.

The data obtained (Table 3) indicate that the root growth of both species was more responsive than shoot growth to the inhibitory allelopathic activity induced by E. dracunculoides. This indicates the organ-based sensitivity of the species to phytotoxic compounds. Previous studies (Tawaha and Turk, 2003; Mushtaq et al., 2010) also documented this aspect of greater root than shoot inhibition. Possible reasons are that roots are the first to emerge and are in direct contact with extracts and thus are exposed to peak periods and concentrations of phytotoxins. Khanh et al. (2005) indicated that the highest level of allopathic suppression may occur when maximum levels of phytotoxins coincided with early stages of plant growth.

\section{CONCLUSIONS}

Based on the results of this study, it can be concluded that phenolic compounds in aqueous extracts of E. dracunculoides can have allelopathic effects on chickpea and wheat growth, including impaired seed germination and retarded seedling growth. Therefore, $E$. dracunculoides should be removed from fields at early stages to prevent harmful effects of this weed on chickpea and wheat crops. 


\section{ACKNOWLEDGEMENTS}

We recognize and are grateful for the financial support provided for these studies by the Higher Education Commission of Pakistan. Our colleague at the Central Hi-Tech Laboratory, Mr. Muddassar Muzzafar is highly appreciated for his technical assistance.

Efectos alelopáticos de fracciones acuosas y orgánicas de Euphorbia dracunculoides Lam. sobre la germinación y crecimiento de plántulas de garbanzo y trigo. Se requiere la identificación de especies de malezas con potencial alelopático y la caracterización de sus efectos adversos en contra de los cultivos asociados para una mejor comprensión de las interacciones cultivosmalezas. Se investigó la actividad fitotóxica de Euphorbia dracunculoides Lam. en la germinación y crecimiento de plántulas de garbanzo (Cicer arietinum L.) y trigo (Triticum aestivum L.) bajo condiciones controladas. Dos estudios separados se realizaron con cada una de las cuatro fracciones de disolventes orgánicos (n-hexano, cloroformo, acetato de etilo, 1-butanol) y extracto acuoso $(1: 10$ y $1: 20)$ de fracciones enteras de plantas de E. dracunculoides usando agua destilada y $0,05 \%(\mathrm{v} / \mathrm{v})$ dimetil sulfóxido (DMSO) como control. Diferentes fracciones acuosas y orgánicas de E. dracunculoides tuvieron una incidencia significativa en los atributos de germinación y crecimiento de las plántulas de las especies evaluadas. El porcentaje de germinación final de trigo no se vio afectado, sin embargo, la elongación de raíces y brotes y la acumulación de biomasa en estas partes fueron significativamente retrasadas. La fracción acuosa fue más fitotóxica que las fracciones orgánicas y disminuyó la germinación de garbanzo en 53\% y 35\% para 1:10 y 1:20, respectivamente. Estas fracciones acuosas, 1:10 y 1:20, también redujeron la longitud de raíces $(75-64 \%$ y $33-34 \%)$ y brotes $(62-18 \%$ y $21-21 \%)$ y el peso seco de raíces $(32-33 \%$ y $42-46 \%)$ y brotes $(32-7 \%$ y $84-$ $80 \%)$ para trigo y garbanzo, respectivamente. Entre las fracciones orgánicas, n-hexano fue la más supresora de las especies ensayadas. El análisis cromatográfico detectó la presencia de cuatro fitotoxinas en la fracción acuosa (1:10) de la planta: ácido furoico, ácido $p$-cumárico, ácido cafeico, y ácido siríngico. El estudio determinó que $E$. dracunculoides es alelopática sobre el trigo y el garbanzo.

Palabras clave: alelopatía, malezas, atributos de germinación, supresión, compuestos fenólicos.

\section{LITERATURE CITED}

Abdul-Baki, B.A.A., and J.D. Anderson. 1973. Relationship between decarboxylation of glutamic acid and vigour in soybean seed. Crop Science 13:227-232.

Abu-Romman, S., M. Shatnawi, and R. Shibli. 2010. Allelopathic effects of spurge (Euphorbia hierosolymitana) on wheat (Triticum durum). American-Eurasian Journal of Agricultural and Environmental Sciences 7:298-302.
Alsaadawi, I.S., F.A.K. Sakeri, and S.M. Al-Dulaimy. 1990 Allelopathic inhibition of Cynodon dactylon (L.) Pers. and other plant species by Euphorbia prostrata L. Journal of Chemical Ecology 16:2747-2754.

Anjum, T., and R. Bajwa. 2010. Sunflower allelochemicals adversely affect wheat yield. Natural Product Research 24:825-837.

AOSA. 1983 Seed vigor hand testing book. Contribution $N^{\circ} 32$ to the handbook on seed testing. Association of Official Seed Analysts (AOSA), Springfield, Illinois, USA.

AOSA. 1990. Rules for testing seeds. Association of Official Seed Analysts (AOSA). Journal of Seed Technology 12:1-112.

Batish, D.R., K. Lavanya, H.P. Singh, and R.K. Kohli. 2007. Phenolic allelochemicals released by Chenopodium murale affect the growth, nodulation and macromolecule content in chickpea and pea. Plant Growth Regulation 51:119-128.

Benyas, E., M.B. Hassanpouraghdam, S.Z. Salmasi, and O.S.K. Oskooei. 2010. Allelopathic effects of Xanthium strumarium L. shoot aqueous extract on germination, seedling growth and chlorophyll content of lentil (Lens culinaris Medic.) Romanian Biotechnological Letters 15:5223-5228.

Blum, U. 1996. Allelopathic interactions involving phenolic acids. Journal of Nematology 28:259-267.

Duke, S.O., and F.E. Dayan. 2006. Modes of action of phytotoxins from plants. p. 511-536. In Reigosa, M.J., N. Pedrol, and L. González (eds.) Allelopathy: A physiological process with ecological implications. Springer, Dordrecht, The Netherlands.

Einhellig, F.A. 1996. Interactions involving allelopathy in cropping systems. Agronomy Journal 88:883-893.

Ellis, R.A., and E.H. Roberts. 1981. The quantification of ageing and survival in orthodox seeds. Seed Science and Technology 9:373409.

Farooq, M., S.M.A. Basra, N. Ahmad, and K. Hafeez. 2005. Thermal hardening: a new seed vigor enhancing tool in rice. Journal of Integrative Plant Biology 47:187-193.

Gniazdowska, A., and R. Bogatek. 2005. Allelopathic interaction between plants. Multi site action of allelochemicals. Acta Physiologiae Plantarum 27:395-407.

Hussain, F. 1980. Allelopathic effect of Pakistani weeds: Euphorbia granulata Forssk. Oecologia 45:267-269.

Iqbal, Z., S. Hiradate, A. Noda, S. Isojama, and Y. Fujii. 2002. Allelopathy of buckwheat: Assessment of allelopathic potential of extract of aerial parts of buckwheat and identification of fagomine and other related alkaloids as allelochemicals. Weed Biology and Management 2:110-115.

Javaid, A., S. Shafique, and S. Shafique. 2010. Herbicidal activity of Withania somnifera against Phalaris minor. Natural Product Research 24:1457-1468.

Javaid, A., S. Shafique, and S. Shafique. 2011. Management of Parthenium hysterophorus (Asteraceae) by Withania somnifera (Solanaceae). Natural Product Research 25:407-416.

Kadioglu, I., Y. Yanar, and U. Asav. 2005. Allelopathic effects of weed leachates against seed germination of some plants. Journal of Environmental Biology 26:169-173.

Khaliq, A., A. Matloob, Z.A. Cheema, and M. Farooq. 2011 Allelopathic activity of sole and mix incorporation of crop residues against rice and its associated grassy weed-jungle rice (Echinochloa colona [L.] Link). Chilean Journal of Agricultural Research 71:418-423.

Khanh, T.D., M.I. Chung, T.D. Xuan, and S. Twata. 2005. The exploitation of crop allelopathy in sustainable agricultural production. Journal of Agronomy and Crop Science 191:172-184.

Li, Z., Q. Wang, X. Ruan, C. Pan, and D. Jiang. 2010. Phenolics and plant allelopathy. Molecules 15:8933-8952.

Manners, G.D. 1987. The role of phytochemistry in attacking the leafy spurge (Euphorbia esula) problem. p. 228-237. In Waller, G.R. (ed.) Allelochemicals: Role in agriculture and forestry, ACS Symposium Series 330. American Chemical Society, Washington, DC., USA.

Marwat, K.B., I.A. Khan, G. Hassan, and N. Khan. 2004. Efficacy of pre and post emergence herbicides for controlling weeds in chickpea. Pakistan Journal of Weed Science Research 10:51-54. 
Mishra, J., S.D. Swain, and V.P. Singh. 2004. Studies on germination and allelopathic potential of horse purslane (Trianthema partulacastrum L.) Indian Journal of Plant Physiology 9:181-184.

Mushtaq, M.N., Z.A. Cheema, and A. Khaliq. 2010. Effect of mixture of allelopathic plant aqueous extracts on Trianthema portulacastrum L. weed. Allelopathy Journal 25:205-212.

Qasem, J.R. 1995. Allelopathic effect of some arable land weeds on wheat (Triticum durum L.): A survey. Dirasat 22:81-97. (In Arabic with English summary)

Qasem, J.R., and C.L. Foy. 2001. Weed allelopathy, its ecological impacts and future prospects. Journal of Crop Production 4:43119.

Rice, E.L. 1964. Inhibition of nitrogen-fixing and nitrifying bacteria by seed plants. Ecology 45:824-837.

Rice, E.L. 1969. Inhibition of nitrogen-fixing and nitrifying bacteria by seed plants. VI. Inhibitors from Euphorbia supina Raf. Physiologia Plantarum 22:1175-1183.

Rice, E.L. 1984. Allelopathy. $2^{\text {nd }}$ ed. Academic Press, Orlando, Florida, USA.

Singh, H.P., D.R. Batish, and R.K. Kohli. 2003. Allelopathic interactions and allelochemicals: new possibilities for sustainable weed management. Critical Review in Plant Sciences 22:239-311.

Sugha, S.K. 1979. Effect of weed extracts on wheat germination. Science and Culture 45:65-66.

Tanveer, A. 2008. Biology and ecology of weeds. 108 p. Higher Education Commission, Islamabad, Pakistan.
Tanveer, A., A. Rehman, M.M. Javaid, R.N. Abbas, M. Sibtain, A.H. Ahmad, et al. 2010. Allelopathic potential of Euphorbia helioscopia L. against wheat (Triticum aestivum L.), chickpea (Cicer arietinum L.) and lentil (Lens culinaris Medic.) Turkish Journal of Agriculture and Forestry 34:75-81.

Tawaha, A.M., and M.A. Turk. 2003. Allelopathic effects of black mustard (Brassica nigra) on germination and growth of wild barley (Hordeum spontaneum). Journal of Agronomy and Crop Science 189:298-303.

Tiwari, S.P., S.S. Bhandauri, M.S. Voddaria, and D. Dayal. 1985. Allelopathic effects of weeds in soybean, groundnut and greengram [Vigna mungo]. Short communication. Current Science $54: 434-435$.

Veenapani, D. 2004. Inhibition in seed germination of Oryza sativa (paddy) by two weed species. Flora and Fauna 10:11-12.

Weir, T.L., S. Park, and J.M. Vivanco. 2004. Biochemical and physiological mechanisms mediated by allelochemicals. Current Opinion in Plant Biology 7:472-479.

Weston, L.A., and S.O. Duke. 2003. Weed and crop allelopathy. Critical Reviews in Plant Sciences 22:367-389.

Whitehead, D.C., M.H. Dibb, and R.D. Hartley. 1981. Extractant pH and the release of phenolic compounds from soils, plant roots and leaf litter. Soil Biology and Biochemistry 13:343-348.

Zieliński, H., and H. Kozłowska. 2000. Antioxidant activity and total phenolics in selected cereal grains and their different morphological fractions. Journal of Agricultural and Food Chemistry 48:2008-2016. 